sional classes of Hampstead, but instead reflect radically different cultural traditions and styles of life ... The objectivity of basic needs is equally delusive. Needs can be given no plausible cross cultural content, but instead are seen to vary across different moral traditions. ${ }^{5}$

The ideology of the New Right rejects any notion of the political manipulation of the allocative efficiency of the market that might redistribute income within or between nations. Just as the New Right rejects. neoKeynesian policies on the state level, so it rejects the last fifty years of statedriven development in the Third World. There is no dual economy of labour, no comparative disadvantage or non-market mentality. Economics is a general science of human behaviour-unless prohibited or violated by politics and morals. The only accountability is what is imposed by the market, namely, a rule against inefficiency but not any rule against inequality. Rather, markets encode inequalities as competitive differences that optimize social efficiency. According to the New Right, there can be no equation between inequality and injustice. The blindness of the market is the ultimate guarantee of merit and reward. Social inequality is natural whereas the policies of equality are unnatural.

\section{Notes}

1. John O'Neill, "The Civic Recovery of Nationhood," International Conference on Civic Society: Globalization, Nationhood and Well-Being. The Laidlaw Foundation/Robarts Centre for Canadian Studies, York University, Toronto, 3-4 April 1995.

2. John O'Neill, The Poverty of Postmodernism (London: Routledge, 1995).

3. Robert W. Cox, Production, Power and World Order: Social Forces in the Making of History (New York: Columbia University Press, 1987), 77-78.

4. Ibid., 289.

5. John Gray, "Classical Liberalisms, Positional Goods, and the Politicization of Poverty," Dilemmas of Liberal Democracies: Studies in Fred Hirsch's Social Limits to Growth (London: Tavistock, 1983), 18182. ם

\title{
Globalization, Refugee Crisis and the Work of International Non-Government Organisations
}

\author{
Robert Holton
}

\section{Abstract}

The author suggests that increasing economic rationalism in the post-Cold War era has engendered a retreat from public moral responsibility along with the hardening of attitudes to refugees. While deconstructing the international refugee system, he focuses on the roles played by non-government organisations within it, arguing that the existence of NGOs does exert a moral influence on nation-states with respect to treatment of refugees. The author asserts a positive view of the role of NGOs in the changing global refugee resettlement regime and argues that NGOs form an important part of international civil society.

\section{Précis}

L'auteur explique que le rationalisme économique accéléré de l'après Guerre Froide a engendré une désaffectation envers les responsabilités morales en matière d'affaires publiques allant de pair avec un net durcissement des attitudes envers les réfugiés. En décomposant le système international d'aide aux réfugiés, l'auteur concentre son attention sur le rôle joué au sein de ce dernier par les organismes non gouvernementaux (ONG). Il développe une argumentation selon laquelle l'existenced'ONG exerce une nette influence morale sur les Etats-Nations en matière de statut des réfugiés. Une vision positive du rôle des ONG, dans la présente perspective de mutation de la doctrine globale de relocalisation des réfugiés, est mise de l'avant par l'auteur. Les ONG sont présentés comme étant un des importants éléments d'une Société Civile Internationale.

Robert Holton is Director, Centre for Multicultural Studies, and Professor of Sociology, Flinders University, Adelaide, Australia.

\section{Globalization and the Refugee Crisis}

It is clearly no exaggeration to speak of a world refugee crisis. Whatever definition of refugee is used, it is clear that very large numbers of people, in the contemporary world, have been forced involuntarily to move from their place of residence.

If refugees are defined as "displaced peoples seeking protection," then most estimates of the numbers involved lie currently between 15-20 million. This total is not simply composed of heroic individuals experiencing personal political persecution, but involves large groups, often including political and cultural minorities.

All of the world's continents are heavily involved, whether as sources of refugees, or in the process of resettlement. As far as sources are concerned, it should be emphasized that in recent years Asia and Africa have become the major theatres of refugee crisis. This in turn is a reflection of the fact that refugee displacement primarily affects the world's poor.

It is legitimate to speak of a refugee crisis, not only because of the large numbers of people involved, but also because of a detectable hardening of attitudes to refugees on the part of the major Western nation-states. With the end of the Cold War, Western states have become almost exclusively preoccupied with economic rationalism. This has involved an increased engagement with the economic side of globalization, but an increased indifference to the global plight of refugees. Meanwhile, the international refugee system, centred on the United Nations, has limited capacities to offset national indifference.

One casualty of the combination of economic rationalism and the retreat

Refuge, Vol. 15, No. 6 (1997) 
from public moral responsibility for refugee resettlement, has been a governmental retreat from public funding of refugee settlement. The system, as it stands, is then unable to deal either with refugee numbers, or with the global scale of refugee crisis.

\section{The Causes of Refugee Crisis}

The causes of refugee crisis are a complex issue, and I have only sketched some very general considerations here. In the first place it may seem that refugee crises are purely national or regional in origin. The immediate cause of population displacement; of large groups and individuals may be linked to a range of endogenous national causes, such as authoritarian denial of human rights to minorities and dissidents, revolution, invasion, civil war, ethnic cleansing, or ecological crisis involving famine and an accompanying breakdown of social order.

There is much to be said for this endogenous approach, but it does have the weakness of isolating individual national or regional refugee crises from the wider international and global environment. This wider environment may impact on national crises in a number of ways. In the first place, much political instability and authoritarianism in particular nations during the Cold War period was underwritten by the political "Super Powers."

Secondly, global economic inequalities between the West and many developing nations, have contributed to subsistence crises and desires for population movement. Not all developing countries lack economic autonomy, but those that do are vulnerable to Western domination, leading to the neglect of domestic priorities such as local food production in favour of production of commodities for the world market.

The twin effect of the globalization of consumer capitalism and of media representations of Western affluence has been to heighten the desire among the populations of many developing countries for entry into the West (Cox 1992). This has further increased demands to move.
But it has simultaneously contributed to the blurring of distinctions between refugees and economic migrants. In seeking refuge, it is very hard for refugees to appreciate the niceties that Western governments insist on making between escape from poverty and escape from political oppression. This is because the sources of poverty and political oppression are so often inextricably bound together, as in regimes where authoritarian politics is a vehicle for the enforcement of free market economics.

Economic globalization is not, however, simply a matter of market exchange, but also of regulation by the more powerful and wealthier nationstates. Economic globalization has been regulated in an uneven way to suit the interests of powerful nations. This means free trade in capital and commodities for Western goods, but highly restricted movements of people and labour, especially where outflows from developing countries are involved.

This approach was ratified at the recent conclusion of the Uruguay round of GATT, which established the World TradeOrganisation (WTO) on a more elaborate basis. There, Western governments reacted with horror to the proposition of the Indian government that the WTO should look at free movement of labour to match the free movement of capital and commodities. This selective approach to economic globalization is linked to a recent tightening and, in some cases, closure of borders against refugees, on the part of Western nations in the European Union, Australia and North America. Increasingly restrictive policies and procedures are evident which limit both refugee numbers, and, in some cases, the countries from which "genuine" refugee applications are accepted.

Speaking in this context to a National Forum on Refugees in Australia in 1992, David Matas $(1992,189)$, identified a parallel between Adam Smith's famous discussion of market restriction, and the growing culture of restrictive thinking among immigra- tion officials. I think this repays retelling.

Adam Smith, you will recall, in The Wealth of Nations wrote, "People of the same trade seldom meet together, even for merriment and diversion, but the conversation ends in a conspiracy against the public, or in some contrivance to raise prices."

Much the same, says Matas, applies to meetings of immigration officials. In his view, they "seldom meet together, but the conversation ends in a conspiracy against freedom of movement, or in some contrivance to hinder protection of refugees."

Is this harsh judgement really fair and accurate?

There are undoubtedly important exclusionist subcultures within Immigration Departments, but these are scarcely by themselves the major determinants of public policy development. Rather, the causes of hardening attitudes and practices are more deepseated. One influential argument about such causes, well known to a Canadian audience, is what Tony Richmond calls the new global apartheid. This interprets the trend toward immigration restriction, as a new form of global apartheid, in which self-interested nations with the power to do so, seal off their borders. Closed borders, in this sense, function to separate populations on the basis of national and cultural origins, protecting the rich and powerful against the poor and oppressed.

What this amounts to then is a failure of the nation-state system to guarantee security for the world's population. This failure is connected with a loss of moral nerve by the governments of wealthier countries. At worst this means that refugees are simply ignored. At best, it involves a highly conditional response, whereby intake is kept to a minimum, governments choose the kinds of refugees they want, and draconian disincentives to illegal refugee entry are adopted.

The consequences of this are twofold. In the first place, there are material effects, such as preclusion from 
entry, forced repatriation, and cutbacks of services to those within. Secondly, there are what might be called discursive consequences. By this, I mean official attempts to change the way we think about refugees. Of particular importance here are attempts to limit the category of who qualifies as a refugee.

Discourse about refugees is both highly political and moralistic (for further discussion of the labelling of refugees, see Zetter 1991). Politically, there has been a detectable shift in official Western attitudes away from positive representations of refugees. In the 1940s and 1950s, European refugees were generally regarded as heroic freedom seekers fleeing fascism or Stalinism. Their resettlement was aided by post-war economic expansion and labour shortage. This positive climate has now been eroded, with the extension of the refugee crisis to Asian and African populations, at a time when Western economies are undergoing restructuring and recession. Within this situation the plight of current refugees cannot be so neatly inserted into Western meta-narratives about the struggle between democracy and totalitarianism. To resettle refugees in the West now requires greater economic sacrifices than in the past, at a time when economic difficulties have helped to fan the flames of racism.

Within this context, the term "refugee" has been given an increasingly restrictive political definition in the West. This is limited essentially to the so-called Convention refugees, namely those who can prove the likelihood of persecution in their country of origin. Others fleeing impending persecution, poverty or ecological crisis are classified as economic migrants fleeing poverty. In the new language, Governments have had increased resort to moralised concepts such as the "genuine" and the "bogus" refugee. In some ways this throws us back to 19th century discourses of the deserving and undeserving poor.

Conflict over who is a refugee reminds us of the dual significance of the term refugee as a classification. This is not only a description of those seeking refuge. It is also an administrative label applied selectively, and I would argue often arbitrarily, by governments and immigration officials to others. Whereas the former approach recognises the integrity of those desperate enough to seek security in another country often at considerable personal risk, the latter approaches refugee issues in a manner expedient to the Realpolitik of the nation-state. Where necessary, this involves de-legitimising the integrity of refugee claims, especially of those deemed to have arrived in an illegal or irregular manner.

To sum up so far, globalization is closely bound up with the refugee crisis. Refugee movements are manifestations of globalization, while global processes are evident both in relation to the causes of the refugee crisis and in responses to it. This kind of global focus does not of course mean that nation-states are irrelevant to refugee issues-far from it. National policies and responses have been and continue to be of considerable importance, both in terms of intake and settlement policy, and in terms of the particular ways that citizenship is understood and constructed. This importance is reflected in variations of national practice which have been of historical importance, even if the current tendency has been towards a convergent hardening of policies against refugees in almost all nations.

\section{References}

Cox, D. 1992. "Australia's Role in the Global Refugee Challenge." In Proceedings of the 'Welcome Stranger' National Forum on Refugees, Sydney 19-21 June 1992, 29-40. Canberra: Australian Catholics Bishops Conference.

Matas, D. 1992. "An NGO Agenda for the UNHCR." In Proceedings of the 'Welcome Stranger' National Forum on Refugees, Sydney 19-21 June 1992, 189-96. Canberra: Australian Catholics Bishops Conference.

Zetter, R. 1991. "The Labelling of Refugees: Forming and Unforming and Identity." Journal of Refugee Studies 4, no. 1:39-62. व

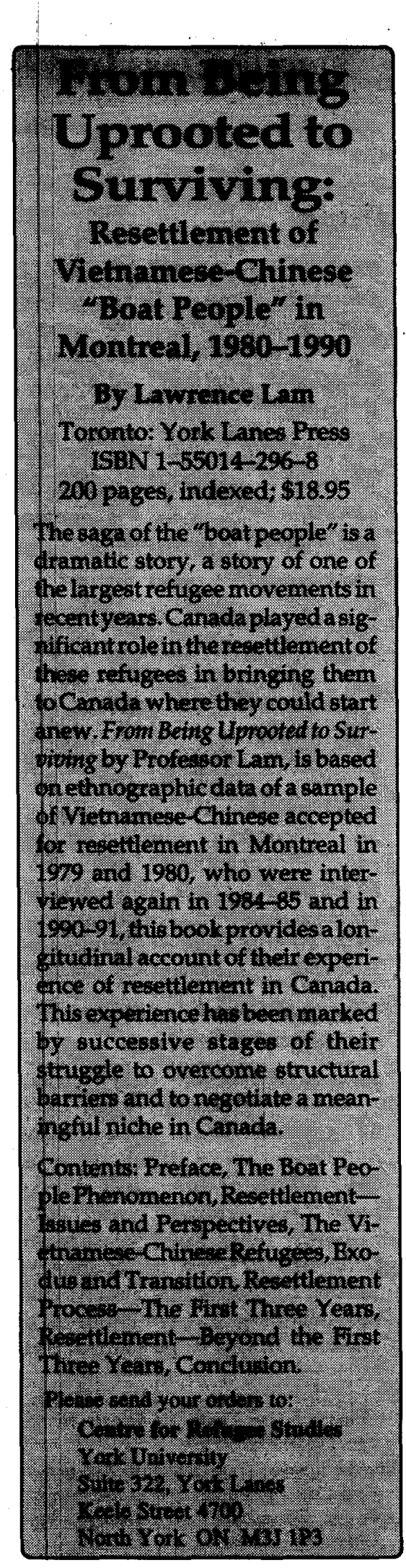

Refuge, Vol. 15, No. 6 (1997) 